\title{
How To Record Journal Entries Correctly For Bonds Issued At A Discount Or A Premium? Hint: Follow The Money
}

Donald T. Joyner, Regent University, USA

\begin{abstract}
A factor that complicates the posting of the journal entries related to the issue of bonds is that the amount of money received by the issuing company may be different from the face value of the bond. If the bond stated rate is higher than the market interest rate at the time of issue of the bond, the company can sell the bond at a premium; on the other hand, if the stated rate is lower than the market interest rate, the company will be forced to sell the bond at a discount. Another complicating factor is that the issuing company has to make interest payments at regular time intervals throughout the life of the bond and a final payment on the date of the maturity of the bond. Many students of Accounting, especially at the undergraduate level, find the journal entries related to the treatment of bond discounts and premiums very confusing, since they are spread over many years, spanning the entire life of the bond, unlike the numerous other journal entries covering the annual operating activities of the company. In this paper, some hints and guidelines are provided with the goal of helping the students record the journal entries correctly when bonds are sold at a discount or a premium.
\end{abstract}

Keywords: Journal Entries for Bond Discounts and Premiums; Interest Payments on Bonds; Amortization of Bond Discounts and Premiums

\section{INTRODUCTION}

ournal entries form the heart of the double-entry bookkeeping system which, in turn, helps you maintain your
company accounts accurately and balance the books at the end of the year. Generally, events that give rise to revenue and expense recognition have an impact on the company accounts for only one year. One of these events is the maintenance of accounts for interest payments associated with the bonds sold at a discount or a premium. According to Generally Accepted Accounting Principles (GAAP) companies should record their transactions using the accrual method of accounting. This means that revenues are recognized when earned and expenses are recognized when incurred. This is in contrast to the cash-basis method of accounting. Under the cash-basis method of accounting, revenues are recognized when cash is received (regardless of when it is earned) and expenses are recognized when paid (regardless of when an expense has actually been incurred). The journal entries related to the amortization of the premium or discount associated with the issue of a bond and the corresponding interest payments to the bondholders highlight the differences between the two methods of accounting. The amount of the principal received from the sale of a bond at the time of issue and the corresponding annual interest expenses charged to the Income Statement do not always equal the amount of the principal re-paid at the time of maturity of the bond and the annual interest paid in cash respectively to the bondholder under the accrual method of accounting.

One of the underlying foundations of GAAP is the periodicity assumption. The periodicity assumption says that the performance of a business entity can be measured on the basis of a specified unit of time. Corporations, which are collectively owned by the public and whose shares are traded on national stock exchanges are required to issue audited financial statements once a year. Even the privately owned companies have to file their (income) tax returns to the IRS once a year. There are four basic financial statements: the Balance Sheet, the Income Statement, the Statement of Changes in Stockholder's Equity and the Statement of Cash Flows. The Balance Sheet represents the values of the assets and liabilities of the business at a specific point in time (example: As of 12/31/17) whereas the other three statements cover a period of time such as a quarter, half-year or a year (example: For the year ending on 12/31/17). 
Accounts maintained by corporations fall into one of two categories: Temporary and Permanent. Temporary accounts include revenues, expenses, and distributions (dividends) to owners. Temporary accounts are closed at the end of each accounting year. Their cumulative effect is transferred to shareholder equity at the end of the year. Permanent accounts are not closed at the end of the year. The Balance Sheet is comprised solely of permanent accounts: assets, liabilities, and stockholder's equity. Throughout the accounting year, transactions are recorded in a General Journal which serves as the 'diary' of the business. In modern industrialized societies, every commercial transaction involves the transfer of cash between a business entity and another outside entity. When posting the journal entries related to the transaction, the hint, "Follow the Money" comes in handy. If money is received by your company, the cash account is debited. If a payment is made to an outside entity, the cash account is credited. According to the double-entry bookkeeping system, for every transaction there should be at least one debit entry and one credit entry and the total of the debit entries must be equal to the total of the credit entries. From a pedagogical point of view, the significance of this statement cannot be overemphasized. In fact, this statement is based on a sound mathematical foundation. The debit entries can be looked upon as the variables on the left side of an algebraic equation and credit entries, as the variables on the right side. If all the journal entries corresponding to a transaction are posted correctly, the total of the left-handside variables must be equal to the total of the right-hand-side variables of the algebraic equation. If you verify this statement consistently for every transaction, reconciliation and closing of the accounts at the end of the year would be relatively fast and easy. Of course, the General Ledger of the business shows the cumulative impact of journal entries as well as the overall balance for each account. At all times, the total of assets must equal the total of the liabilities and stockholder's equity.

Now consider some examples. In most businesses, employee travel expenses impact only one reporting period. The journal entries covering employee travel expenses are relatively simple and the accounts are closed at the end of the year, if the expenses pertain to just the current accounting year. In such cases, the employee travel expenses account is a temporary account. The journal entries related to the sales and purchases of goods are also somewhat simple, but almost always affect more than one accounting period. Final sales are recorded as revenue and are closed at the end of the year. Similarly, the costs associated with the production of the goods sold are recorded as expenses and closed at the end of the year (generally, under the heading "Cost of Goods Sold"). If all goods available for sale are not sold or raw materials purchased for use in production are not completely consumed, it will result in an ending inventory balance of finished goods, work-in-progress, raw materials, and consumables, etc. These accounts are merely carried forward from one year to the next, and are, in one sense, limited in scope to just one year, and therefore, may properly be classified as temporary accounts.

In contrast, you will encounter a higher degree of complexity in posting journal entries pertaining to bonds. The entries are generally spread over many years, and often require complicated calculations involving bond discounts or bond premiums. However, a fixed cash payment is made at fixed intervals of time each year to the bondholder. The main difficulty in recording the entries lies in determining how much of the cash payment goes into interest expense and how much is debited or credited to the accounts related to the amortization of the bond premium or discount. Any account dealing with the amortization of the bond premium or discount may be called a permanent or long-term account since it is carried in the books of the issuing company for many years.

In all undergraduate Business Curricula, journal entries are generally discussed in the first Accounting Course (MillerNobles, Mattison, \& Matsumura, 2015) at the freshman or sophomore level. But, the first Accounting Course is meant as an introduction to basic accounting concepts and does not cover the material as complex as journal entries for corporate bonds. That topic is normally reserved for a course in Intermediate Accounting (Gordon, Raedy, \& Sannella, 2015) which may or may not require a course in Corporate Finance (Ehrhardt \& Brigham, 2016) as a prerequisite. There are several excellent textbooks on the subjects of Financial Accounting, Intermediate Accounting, and Corporate Finance. The author has no preference for any specific textbook, but has merely listed three of them as relevant references so that the interested reader could readily refer to them. Even if the students learn the different aspects of bonds in Corporate Finance, it doesn't mean they will understand the journal entries taught in an Intermediate Accounting course. Most students find the discussion related to the recording of journal entries for bonds confusing. It is fair to say that, in general, many undergraduate Accounting students find the topic of posting journal entries for bonds difficult, and in particular, the students find the word "amortization" itself perplexing. In this paper, some hints and guidelines are provided with the goal of helping the students record the journal entries correctly when bonds are sold at a discount or a premium. 


\section{WHAT IS A BOND?}

The word "bond" has many different meanings in English language. However, in the world of Corporate Accounting and Finance, the word "bond" has a specific and special meaning and refers simply to a document, inscribed with financial terms, used as a mechanism to exchange money between borrowers and lenders. Companies, large and small, need to borrow funds from investors to finance their current operations or buy new equipment. Obviously, investors demand a return on the money they lend to the companies. Instead of entering into a separate contract with each of the investors, companies, in need of funds, would like to borrow money by issuing a standard contract, stipulating the terms and conditions applicable to the re-payment of the money they are borrowing. The document describing the standard contract is called the "bond" in business parlance and it provides the following information on the document or certificate given to each of the investors (or buyers of the bonds).

(a) Face Value of the Bond - Amount the company expects to borrow in exchange for the bond

(b) Maturity Date of the Bond -- The time when the company will repay the principal or face value of the bond

(c) Stated Rate - The nominal annual rate, stated on the bond, at which interest is paid to the bondholder

(d) Frequency of interest payments - How often the interest is paid in a year to the bondholder

Example: If a company issues a bond with a face value of $\$ 10,000$, at a stated rate of $8 \%$, interest payable semiannually, and maturity of 15 years, then, it has to pay interest twice a year for the next 15 years. Since the interest is paid semi-annually (twice a year), the effective interest rate is $4 \%$ (equal to stated rate/2) for the semi-annual period, and the investor, who paid $\$ 10,000$ for the bond on the date of the issue, will receive 30 payments of $\$ 400$ (equal to $10000 * 0.04)$ at the end of every semi-annaul period from the date of issue of the bond. The $30^{\text {th }}$ payment will also include repayment of the principal of $\$ 10,000$.

\section{DISCOUNT OR PREMIUM ASSOCIATED WITH THE ISSUE OF A BOND}

Often, it takes several months for a company to prepare for the issue of the bonds to the investing public. Bond issuance is a highly legalistic process and companies wishing to issue bonds will hire an underwriter to handle the formal and legal process of bond issuance. Sometimes the financial markets undergo rapid changes in a span of a just a few days. Therefore, the bond stated rate (also called coupon rate in some cases) offered by the company may be different from the prevailing interest rates in the financial markets. Instead of changing the terms and conditions of the bond which may cause a significant delay, the issuing company may simply prefer to accept an amount of money different from the face value of the bond, but keep all the terms and conditions the same. In other words, the company may receive more or less than the face value of the bond, but it still has to pay interest at the stated rate on the face value, and also the amount equal to the face value to the bondholder at the time of maturity. Intuitively, you can see that if the bond stated rate is higher than the market interest rate, an investor will be willing to pay more than the face value of the bond. The extra amount received by the company is called "premium." On the other hand, if the bond stated rate is lower than the market interest rate, an investor will only be willing to pay an amount less than the face value of the bond. The difference between the face value and the amount received is called "discount." If both the stated rate and market rate are equal, an investor will pay face value, and then, in business parlance, the bond is sold at "par." It is worth noting here that at the time of maturity, the investor will receive an amount equal to the face value of the bond, regardless of the amount paid at the time of purchase. It must be clear to you at this point that there is a lot more to the issue and repayment or redemption of a bond than meets the eye. Of course, you can use the internet search engines such as google or bing to learn more about the bonds. If you use the key words or phrases such as "issue of bonds at a discount or premium" or "journal entries for bonds," in your internet search, literally thousands of website names will show up in the list, many with attached video clips. It is almost impossible to discern which one has the relevant information you are looking for. After going through many such websites, the author has provided the references or links to just a few of them that are deemed comprehensive or relevant to the subject matter under discussion. 


\section{JOURNAL ENTRIES FOR A BOND ISSUED AT PAR}

As a starting point, first, assume that the funds associated with the issue of the bond are received on January 1, 20xx, and the company's tax-reporting-year coincides with the calendar year. This will eliminate the need to calculate the accrued interest and the associated but unwarranted complication of recording journal entries for the accrued interest, as discussed in Averkamp (2017). When a bond is sold at par, the journal entries are relatively simple, as described in Ingram (2017). In posting the journal entries, refer to the hint "Follow the Money." At the time of issue, money is received by the company. Therefore, the cash account is debited. Of course, as a contra-entry, the Bonds Payable accounted is credited. Only at the time of maturity, when the bond is re-paid or redeemed, these entries are reversed. The Bonds Payable account will remain on the books as a long-term liability until the maturity of the bond. As far as the interest on the bond is concerned, a fixed cash payment equal to the amount of the interest, calculated at the effective rate for the length of the time period specified in the bond, is made to the bondholder at fixed intervals of time in a year, and, in effect, money goes out of the company. Therefore, following the money, credit the cash account, and debit the interest expense account with the same amount of money at the times when payments are made.

\section{AMORTIZATION OF A BOND DISCOUNT OR PREMIUM}

Amortization refers to a payment schedule that may be spread over just a few months or many years according to which a borrower pays pre-determined amounts of money to a lender on specified dates so that the loan or debt is completely paid-off. Amortization is, in essence, a process to recover through installments the total value of an intangible asset created by an initial investment or loan or other financial transaction. When a bond is sold at par, from the previous discussion, it is clear that posting the corresponding journal entries is a relatively simple matter. However, when the bond is issued at a discount, the borrower receives less than the face value of the bond. But at the time of maturity, the borrower has to pay the full face value. How does the borrower accumulate the funds needed to make up for the shortfall or discount? The process of accumulating the funds equal to the amount of the discount is called amortization of the discount and is described in Averkamp (2017), Bragg (2014), and Ingram (2017). In this case, a difficulty arises in determining how much of the cash payment made to the bondholder goes into interest expense and how much pertains to the amortization of the bond discount. In contrast, the premium is the excess amount received by the bondholder. Now, the borrower has to draw funds from original premium to cover for the shortfall in the interest payments to the lender. Though there is no recovery involved here, the process is still called the amortization of premium. You may interpret the amortization process in case of the bond discount or premium merely as a way making adjustments to the interest expense charged to the Income Statement so that you will be able to make the periodic interest payments as well the final payment to the bondholder.

\section{JOURNAL ENTRIES FOR A BOND ISSUED AT A DISCOUNT EFFECTIVE INTEREST RATE METHOD}

When the bond stated rate is lower than the market interest rate, the bond is sold at a discount, and the issuing company will receive less than the face value of the bond. As an example, suppose that on December 31, 2016, your company issued bonds worth $\$ 300,000$ at a stated rate of $10 \%$, interest payable semi-annually, with a maturity date December 31,2020 . Further, assume the nominal (annual) market interest rate on the date of issue is $12 \%$. Note that these are hypothetical numbers and do not correspond to the actual interest rates (which were a lot lower than the ones given here). Then, using the present value concepts and associated mathematical calculations, an investor has come up with a market price of only $\$ 281,371$ for the bond and your company agreed to sell the bond at that price. Then, the discount offered by your company on the bond is $\$ 18,629(=300000-281371)$. But, on December 31, 2020, your company is required to pay the full face value of $\$ 300,000$ to the bondholder. It implies that you need to somehow accumulate the amount equal to the discount (or shortfall) of $\$ 18,629$ by the end of the fourth year. Since there are eight semiannual periods before the maturity of the bond, you set aside some amount at the end of each of these periods till the date of maturity. The money you received for the bond is treated as the book value of the bond. Since some money is set aside every semi-annual period to make up for the shortfall, that money is added to the initial book value of the bond, so that the final book value at the time of maturity will be equal to the face value. According to GAAP, the recommended procedure for accomplishing this task involves what is known as the effective interest rate method and is illustrated below in a simple and easily understandable way. The steps involved in this procedure are also described in a slightly different fashion in Averkamp (2017), Bragg (2014), and Ingram (2017). 
Calculations for Semi-Annual Period \#1 from the beginning date of 1/1/17 to the ending date of 6/30/17:

Stated rate or the annual nominal interest rate on the bond $=10 \%$.

Since interest is payable semi-annually, periodic interest rate of the bond $=$ stated rate $/ 2=10 \% / 2=5 \%$

Amount of interest payable every semi-annual period $=300000 * 0.05=15000$

Market value (or book value) of the bond at the beginning of the first period $=\$ 281,371$ (see Appendix)

Nominal (annual) market interest rate $=12 \%$.

Again, effective market interest rate for the semi-annual period $=12 \% / 2=6 \%$

Amount of interest on the market value of the bond for the first semi-annual period $=281371 * 0.06=16882$

Here is an interesting fact about the interest on the bond. You are required to pay only $\$ 15,000$ to the bondholder every semi-annual period, but you are allowed to deduct the amount of $\$ 16,882$ as an interest expense in determining the Net Income of the company. The extra amount of interest expense you are allowed to deduct is the amount that is set aside so that it can be used to increase the book value of the bond and reduce the amount of discount.

Extra interest deductible on the Income Statement $=16882-15000=1882$

Book value of the bond at the end of the first period $=281371+1882=283253$.

Amount of discount at the beginning of the first period $=18629$

Amount of discount at the end of the first period $=18629-1882=16747$.

These calculations can be repeated for periods 2 through 8 with the understanding that the book value of the bond at the end of one period will be the book value at the beginning of the next period. The detailed calculations are shown in Table 1. Note that in all these calculations, it is assumed that the market interest rate does not change from one period to the next. Also, for period \#1, all the data are taken from the calculations given above. From period \#2 onwards, the following formulas are used in calculating the cell values:

(a) In column $\mathrm{C}$, the (beginning) book value of the bond in any period is equal to the book value from the previous row (or period) of column F.

(b) Column $\mathrm{D}=($ Column $\mathrm{C}) * 0.06$ in every row

(c) Column $\mathrm{E}=$ Column $\mathrm{D}-15000$ in every row

(d) Column $\mathrm{F}=($ Previous value in Column $\mathrm{F})+($ current value in Column $\mathrm{E})$

(e) Column $\mathrm{G}=($ Previous value in Column $\mathrm{G})-($ current value in Column E)

Table 1. Interest Calculations for a Bond Sold at a Discount -Effective Interest Rate Method

\begin{tabular}{|c|c|c|c|c|c|c|}
\hline $\begin{array}{c}\text { Semi- } \\
\text { Annual } \\
\text { Period } \\
\text { Number }\end{array}$ & $\begin{array}{c}\text { Beginning and } \\
\text { ending dates of the } \\
\text { semi-annual } \\
\text { period }\end{array}$ & $\begin{array}{c}\text { Book value of the } \\
\text { bond at beginning } \\
\text { of semi-annual } \\
\text { period }\end{array}$ & $\begin{array}{c}\text { Amount of } \\
\text { interest for the } \\
\text { semi-annual } \\
\text { period }\end{array}$ & $\begin{array}{c}\text { Extra Interest } \\
\text { paid on the book } \\
\text { value of the } \\
\text { bond }\end{array}$ & $\begin{array}{c}\text { Book value of } \\
\text { the bond at the } \\
\text { end of semi- } \\
\text { annual period }\end{array}$ & $\begin{array}{c}\text { Net amount of } \\
\text { discount at the } \\
\text { end of semi- } \\
\text { annual period }\end{array}$ \\
\hline $\mathbf{A}$ & $\mathbf{B}$ & $\mathbf{C}$ & $\mathbf{D}$ & $\mathbf{E}$ & $\mathbf{F}$ & $\mathbf{G}$ \\
\hline 1 & $1 / 1 / 17-6 / 30 / 17$ & $\$ 281,371$ & $\$ 16,882$ & $\$ 1,882$ & $\$ 283,253$ & $\$ 16,747$ \\
\hline 2 & $7 / 1 / 17-12 / 31 / 17$ & $\$ 283,253$ & $\$ 16,995$ & $\$ 1,995$ & $\$ 285,248$ & $\$ 14,752$ \\
\hline 3 & $1 / 1 / 18-6 / 30 / 18$ & $\$ 285,248$ & $\$ 17,115$ & $\$ 2,115$ & $\$ 287,363$ & $\$ 12,637$ \\
\hline 4 & $7 / 1 / 18-12 / 31 / 18$ & $\$ 287,363$ & $\$ 17,242$ & $\$ 2,242$ & $\$ 289,605$ & $\$ 10,395$ \\
\hline 5 & $1 / 1 / 19-6 / 30 / 19$ & $\$ 289,605$ & $\$ 17,376$ & $\$ 2,376$ & $\$ 291,981$ & $\$ 8,019$ \\
\hline 6 & $7 / 1 / 19-12 / 31 / 19$ & $\$ 291,981$ & $\$ 17,519$ & $\$ 2,519$ & $\$ 294,500$ & $\$ 5,500$ \\
\hline 7 & $1 / 1 / 20-6 / 30 / 20$ & $\$ 294,500$ & $\$ 17,670$ & $\$ 2,670$ & $\$ 297,170$ & $\$ 2,830$ \\
\hline 8 & $7 / 1 / 20-12 / 31 / 20$ & $\$ 297,170$ & $\$ 17,830$ & $\$ 2,830$ & $\$ 300,000$ & \\
\hline
\end{tabular}


The next step is to post the journal entries. Again, refer to the hint: "Follow the Money." On January 1, 2017, an amount of $\$ 281,371$ is received. Obviously, you debit the Cash Account with $\$ 281,371$. Also, a long-term liability equal to the face value of $\$ 300,000$ is created when the bond is issued. Therefore, you credit the Bonds Payable Account with $\$ 300,000$. The only question is what to do with the Discount? Recall the cardinal principle of the doubleentry system: "the total of the debits must be equal to the total of the credits." In this case, the debit entry is less than the credit entry, since you received less than the face value. Therefore, in order to balance the books, you need to create a new account under the name "Discount on Bonds Payable," and debit it with the difference or discount amount of $\$ 18,629$. On June 30,2017 , your company makes a payment $\$ 15,000$ to the bondholder. This is a cash outflow. Obviously, you credit the Cash Account with $\$ 15,000$. Since this is a credit, the corresponding Interest Expense Account is debited with, not the amount of $\$ 15,000$, but the allowable deduction of $\$ 16,882$. As noted earlier, the extra amount of interest is used to reduce the Discount on the Bonds Payable. Therefore, to balance the entries related to the interest, you credit the Discount on Bonds Payable Account with the extra amount of $\$ 1,882$. Similar remarks apply for all the semi-annual periods, except that the amounts debited to the Interest Expense Account will continue to go up. Similarly, the amounts credited to Discount on Bonds Payable Account will also go up. Finally, when the company makes the payment of $\$ 300,000$ to the bondholder on the date of maturity of the bond, the Cash Account is credited and the Bonds Payable Account is debited. Also, the total credits of the Discount on Bonds Payable Account will be equal to the initial debit entry of $\$ 18,629$. All the accounts related to the issue of the bond can be closed on December 31, 2020. The journal entries based on the effective interest rate method for a bond sold at a discount are shown in Table 2.

Table 2. Journal Entries for a Bond Sold at a Discount -Effective Interest Rate Method

\begin{tabular}{|c|c|c|c|}
\hline \multicolumn{4}{|c|}{ Journal Entries for a Bond Sold at Discount } \\
\hline Date & Account Name & Debit & Credit \\
\hline \multirow{3}{*}{ 1-Jan-17 } & Cash & 281,371 & \\
\hline & Discount on Bonds Payable & 18,629 & \\
\hline & Bonds Payable & & 300,000 \\
\hline \multirow{3}{*}{ 30-Jun-17 } & Interest Expense & 16,882 & \\
\hline & Discount on Bonds Payable & & 1882 \\
\hline & Cash & & 15,000 \\
\hline \multirow{3}{*}{ 31-Dec-17 } & Interest Expense & 16,995 & \\
\hline & Discount on Bonds Payable & & 1995 \\
\hline & Cash & & 15,000 \\
\hline \multirow{3}{*}{ 30-Jun-18 } & Interest Expense & 17,115 & \\
\hline & Discount on Bonds Payable & & 2115 \\
\hline & Cash & & 15,000 \\
\hline \multirow{3}{*}{ 31-Dec-18 } & Interest Expense & 17,242 & \\
\hline & Discount on Bonds Payable & & 2242 \\
\hline & Cash & & 15,000 \\
\hline \multirow{3}{*}{ 30-Jun-19 } & Interest Expense & 17,376 & \\
\hline & Discount on Bonds Payable & & 2376 \\
\hline & Cash & & 15,000 \\
\hline \multirow{3}{*}{ 31-Dec-19 } & Interest Expense & 17,519 & \\
\hline & Discount on Bonds Payable & & 2519 \\
\hline & Cash & & 15,000 \\
\hline \multirow{3}{*}{ 30-Jun-20 } & Interest Expense & 17,670 & \\
\hline & Discount on Bonds Payable & & 2670 \\
\hline & Cash & & 15,000 \\
\hline \multirow{3}{*}{ 31-Dec-20 } & Interest Expense & 17,830 & \\
\hline & Discount on Bonds Payable & & 2830 \\
\hline & Cash & & 15,000 \\
\hline \multirow{2}{*}{ 31-Dec-20 } & Bonds Payable & 300000 & \\
\hline & Cash & & 300000 \\
\hline
\end{tabular}




\section{JOURNAL ENTRIES FOR A BOND ISSUED AT A PREMIUM EFFECTIVE INTEREST RATE METHOD}

When the bond stated rate is higher than the market interest rate, the bond is sold at a premium, and the issuing company will receive more than the face value of the bond. As an example, suppose that on January 1, 2017, your company issued bonds worth $\$ 300,000$ at a stated rate of $10 \%$, interest payable semi-annually, with a maturity date December 31, 2020. Further, assume that the nominal (annual) market interest rate on the date of issue is $8 \%$. Note that these are hypothetical numbers and do not correspond to the actual interest rates (which were a lot lower than the ones given here). Then, using the present value concepts and associated mathematical calculations, an investor has come up with a market price of $\$ 320,198$ for the bond and your company agreed to sell the bond at that price. Then, the premium offered by buyer of the bond is $\$ 20,198(=320198-300000)$. Of course, on December 31, 2020, your company is required to pay only the face value of $\$ 300,000$ to the bondholder. Does it mean that your company can keep the premium and treat it as a profit (or capital gain)? In this case, the periodic interest on the book value of the bond at the effective market interest rate will be less than the interest due every period to the bondholder. you will use the premium to pay the shortfall in the interest due to the bondholder. Again, when you reach the date of maturity, the premium will be reduced to zero. The procedure for accomplishing this task is illustrated below in a simple and easily understandable way. The steps involved in this procedure are also described in a slightly different fashion in Averkamp (2017), Bragg (2010), and Ingram (2017).

Semi-Annual Period \#1 from the beginning date of 1/1/17 to the ending date of 6/30/17:

Stated rate of the bond $=10 \%$.

Since interest is payable semi-annually, periodic interest rate of the bond $=$ stated rate $/ 2=10 \% / 2=5 \%$

Amount of interest payable every semi-annual period $=300000 * 0.05=15000$

Market value (or book value) of the bond at the beginning of the first period $=\$ 320,198$ (see Appendix)

Nominal market interest rate $=8 \%$.

The effective market interest rate for the semi-annual period $=8 \% / 2=4 \%$

Amount of interest on the market value of the bond for the semi-annual period $=320198 * 0.04=12808$

In this case, you are allowed to charge the amount of only $\$ 12,808$ as an interest expense in arriving at the Net Income of the company. But, your company has to pay $\$ 15,000$ to the bondholder every semi-annual period, and there is a shortfall of $\$ 2,192(=15000-12808)$ in the first period. This shortfall can be made up from the premium paid by the buyer of the bond at the time of the issue. The premium and the book value of the bond also will be reduced by the amount of the shortfall.

Shortfall in interest $=15000-12808=2192$

Book value of the bond at the end of the first period $=320198-2192=318006$

Amount of premium at the beginning of the first period $=20198$

Amount of premium at the end of the first period $=20198-2192=18006$

These calculations can be repeated for periods 2 through 8 with the understanding that the book value of the bond at the end of one period will be the book value at the beginning of the next period. The detailed calculations are shown in Table 3. Note that in all these calculations, it is assumed that the market interest rate does not change from one period to the next. Also, for period \#1, all the data are taken from the calculations given above. From period \#2 onwards, the following formulas are used in calculating the cell values:

(a) In column $\mathrm{C}$, the (beginning) book value of the bond in any period is equal to the book value from the previous row (or period) of column F.

(b) Column $\mathrm{D}=($ Column $\mathrm{C}) * 0.04$ in every row

(c) Column $\mathrm{E}=15000-$ Column $\mathrm{D}$ in every row

(d) Column $\mathrm{F}=($ Previous value in Column $\mathrm{F})-($ current value in Column $\mathrm{E})$

(e) Column $\mathrm{G}=($ Previous value in Column $\mathrm{G})-($ current value in Column E)

Note that some formulas are different from the ones given in Table 1. 
Table 3. Interest Calculations for a Bond Sold at a Premium -Effective Interest Rate Method

\begin{tabular}{c|c|c|c|c|c|c|c|}
\hline $\begin{array}{c}\text { Semi- } \\
\text { Annual } \\
\text { Period } \\
\text { Number }\end{array}$ & $\begin{array}{c}\text { Beginning and } \\
\text { ending dates of the } \\
\text { semi-annual } \\
\text { period }\end{array}$ & $\begin{array}{c}\text { Book value of the } \\
\text { bond at beginning } \\
\text { of semi-annual } \\
\text { period }\end{array}$ & $\begin{array}{c}\text { Amount of } \\
\text { interest for the } \\
\text { semi-annual } \\
\text { period }\end{array}$ & $\begin{array}{c}\text { Shortfall in } \\
\text { interest payable } \\
\text { on the bond }\end{array}$ & $\begin{array}{c}\text { Book value of } \\
\text { the bond at the } \\
\text { end of semi- } \\
\text { annual period }\end{array}$ & $\begin{array}{c}\text { Net amount of } \\
\text { premium at the } \\
\text { end of semi- } \\
\text { annual period }\end{array}$ \\
\hline $\mathbf{A}$ & $\mathbf{B}$ & $\mathbf{C}$ & $\mathbf{D}$ & $\mathbf{E}$ & $\mathbf{F}$ & $\mathbf{G}$ \\
\hline 1 & $1 / 1 / 17-6 / 30 / 17$ & $\$ 320,198$ & $\$ 12,808$ & $\$ 2,192$ & $\$ 318,006$ & $\$ 18,006$ \\
\hline 2 & $7 / 1 / 17-12 / 31 / 17$ & $\$ 318,006$ & $\$ 12,720$ & $\$ 2,280$ & $\$ 315,726$ & $\$ 15,726$ \\
\hline 3 & $1 / 1 / 18-6 / 30 / 18$ & $\$ 315,726$ & $\$ 12,629$ & $\$ 2,371$ & $\$ 313,355$ & $\$ 13,355$ \\
\hline 4 & $7 / 1 / 18-12 / 31 / 18$ & $\$ 313,355$ & $\$ 12,534$ & $\$ 2,466$ & $\$ 310,890$ & $\$ 10,890$ \\
\hline 5 & $1 / 1 / 19-6 / 30 / 19$ & $\$ 310,890$ & $\$ 12,436$ & $\$ 2,564$ & $\$ 308,325$ & $\$ 8,325$ \\
\hline 6 & $7 / 1 / 19-12 / 31 / 19$ & $\$ 308,325$ & $\$ 12,333$ & $\$ 2,667$ & $\$ 305,658$ & $\$ 5,658$ \\
\hline 7 & $1 / 1 / 20-6 / 30 / 20$ & $\$ 305,658$ & $\$ 12,226$ & $\$ 2,774$ & $\$ 302,885$ & $\$ 2,885$ \\
\hline 8 & $7 / 1 / 20-12 / 31 / 20$ & $\$ 302,885$ & $\$ 12,115$ & $\$ 2,885$ & $\$ 300,000$ & \\
\hline
\end{tabular}

As in the case of the bond issued at a discount, your next step is to post the journal entries. However, in this case, the bond is issued at a premium. Of course, again, refer to the hint: "Follow the Money." This will tell you that some entries will be similar, and some will be the opposite of what you did before. On January 1, 2017, an amount of \$320, 198 is received. Obviously, you debit the Cash Account with $\$ 320198$. Also, a long-term liability equal to the face value of $\$ 300,000$ is created when the bond is issued. Therefore, you credit the Bonds Payable Account with $\$ 300,000$. The only question is what to do with the Premium? Since you received more than the face value, to balance the books, you need to create a new account under the name "Premuim on Bonds Payable," and credit it with the difference or premium amount of $\$ 20198$. On June 30, 2017, your company makes a payment $\$ 15,000$ to the bondholder. This is a cash outflow. Obviously, you credit the Cash Account with $\$ 15,000$. But the allowable deduction is not $\$ 15,000$, but only $\$ 12,808$. Therefore, the corresponding Interest Expense Account is debited with, not the amount of $\$ 15,000$, but the allowable deduction of $\$ 12,808$. As noted earlier, the shortfall in the amount of interest is used to reduce the premium on the Bonds Payable. Therefore, to balance the entries related to the interest, you debit the Premium on Bonds Payable Account with the shortfall amount of $\$ 2,192$. Similar remarks apply for all the semi-annual periods, except that the amounts debited to the Interest Expense Account will continue to go down. But, the amounts debited to the Premium on Bonds Payable Account will go up. Finally, when the company makes the payment of $\$ 300,000$ to the bondholder on the date of maturity of the bond, the Cash Account is credited, and the Bonds Payable Account is debited. Also, the total debits of the Premium on Bonds Payable Account will be equal to the initial credit entry of $\$ 20,198$. All the accounts related to the issue of the bond can be closed on December 31, 2020. The journal entries based on the effective interest rate method for a bond sold at a premium are shown in Table 4.

Looking at the four tables, you can make some interesting observations. For the bond sold at a Discount, the interest expense is always higher than the actual interest paid to the bondholder in every semi-annual period. However, for the bond sold at a premium, the interest expense is always lower the actual interest paid to the bondholder in every semi-annual period. The common observation is that in both cases, the values in column E are positive, the last entry in Column F is $\$ 300,000$, the face value of the bond, and in Column G, the last entry is zero. Are these merely coincidences in this particular case because of the way the stated and market interest rate values are selected? Or, is there a basic theory that would always guarantee this convergence of values? It can be proved mathematically that the pattern of the results you see in Tables 1 and 3 is not coincidental, but always true. The proof is given in the Appendix. Though the present value concepts and related formulas are presented in every textbook on Corporate Finance, the author has not come across any proof related to the results shown in columns E, F, and G of Tables 1 and 3. 
Table 4. Journal Entries for a Bond Sold at a Premium -Effective Interest Rate Method

\begin{tabular}{|c|c|c|c|}
\hline \multicolumn{4}{|c|}{ Journal Entries for a Bond Sold at Premium } \\
\hline Date & Account Name & Debit & Credit \\
\hline \multirow{3}{*}{ 1-Jan-17 } & Cash & 320,198 & \\
\hline & Premium on Bonds Payable & & 20198 \\
\hline & Bonds Payable & & 300,000 \\
\hline \multirow{3}{*}{ 30-Jun-17 } & Interest Expense & 12,808 & \\
\hline & Premium on Bonds Payable & 2,192 & \\
\hline & Cash & & 15,000 \\
\hline \multirow{3}{*}{ 31-Dec-17 } & Interest Expense & 12,720 & \\
\hline & Premium on Bonds Payable & 2,280 & \\
\hline & Cash & & 15,000 \\
\hline \multirow{3}{*}{ 30-Jun-18 } & Interest Expense & 12,629 & \\
\hline & Premium on Bonds Payable & 2,371 & \\
\hline & Cash & & 15,000 \\
\hline \multirow{3}{*}{ 31-Dec-18 } & Interest Expense & 12,534 & \\
\hline & Premium on Bonds Payable & 2,466 & \\
\hline & Cash & & 15,000 \\
\hline \multirow{3}{*}{ 30-Jun-19 } & Interest Expense & 12,436 & \\
\hline & Premium on Bonds Payable & 2,564 & \\
\hline & Cash & & 15,000 \\
\hline \multirow{3}{*}{ 31-Dec-19 } & Interest Expense & 12,333 & \\
\hline & Premium on Bonds Payable & 2,667 & \\
\hline & Cash & & 15,000 \\
\hline \multirow{3}{*}{ 30-Jun-20 } & Interest Expense & 12,226 & \\
\hline & Premium on Bonds Payable & 2,774 & \\
\hline & Cash & & 15,000 \\
\hline \multirow{3}{*}{ 31-Dec-20 } & Interest Expense & 12,115 & \\
\hline & Premium on Bonds Payable & 2,885 & \\
\hline & Cash & & 15,000 \\
\hline \multirow{2}{*}{ 31-Dec-20 } & Bonds Payable & 300000 & \\
\hline & Cash & & 300000 \\
\hline
\end{tabular}

From a pedagogical point of view, it is worth noting here that though the effective interest rate method is the one recommended or approved by GAAP, there are other methods that deserve your attention. For example, you can also use the straight line method for the amortization of the bond discount or premium. In fact, the straight line method is relatively simple to understand and implement. For purposes of comparison, the straight line is method is discussed below, but it is not the recommended method. Details of the straight-line method can be found in Averkamp (2017), and Ingram (2017). 


\section{JOURNAL ENTRIES FOR A BOND ISSUED AT A DISCOUNT STRAIGHT LINE METHOD}

In this case, the amount of discount is evenly distributed among the eight semi-annual periods. The amount credited to Discount on Bonds Payable Account is equal to 2328.63 (=18629/8). The interest expense would be equal to $\$ 17,328.63$ (=2368.63+15000). The corresponding journal entries are relatively simple as shown in Table 5 .

Table 5. Journal Entries for a Bond Sold at a Discount - Straight Line Method

\begin{tabular}{|c|c|c|c|}
\hline \multicolumn{4}{|c|}{ Journal Entries for a Bond Sold at Premium } \\
\hline Date & Account Name & Debit & Credit \\
\hline \multirow{3}{*}{ 1-Jan-17 } & Cash & 281,371 & \\
\hline & Discount on Bonds Payable & 18,629 & \\
\hline & Bonds Payable & & 300,000 \\
\hline \multirow{3}{*}{ 30-Jun-17 } & Interest Expense & $17,328.63$ & \\
\hline & Discount on Bonds Payable & & 2328.63 \\
\hline & Cash & & 15,000 \\
\hline \multirow{3}{*}{ 31-Dec-17 } & Interest Expense & $17,328.63$ & \\
\hline & Discount on Bonds Payable & & 2328.63 \\
\hline & Cash & & 15,000 \\
\hline \multirow{3}{*}{ 30-Jun-18 } & Interest Expense & $17,328.63$ & \\
\hline & Discount on Bonds Payable & & 2328.63 \\
\hline & Cash & & 15,000 \\
\hline \multirow{3}{*}{ 31-Dec-18 } & Interest Expense & $17,328.63$ & \\
\hline & Discount on Bonds Payable & & 2328.63 \\
\hline & Cash & & 15,000 \\
\hline \multirow{3}{*}{ 30-Jun-19 } & Interest Expense & $17,328.63$ & \\
\hline & Discount on Bonds Payable & & 2328.63 \\
\hline & Cash & & 15,000 \\
\hline \multirow{3}{*}{ 31-Dec-19 } & Interest Expense & $17,328.63$ & \\
\hline & Discount on Bonds Payable & & 2328.63 \\
\hline & Cash & & 15,000 \\
\hline \multirow{3}{*}{ 30-Jun-20 } & Interest Expense & $17,328.63$ & \\
\hline & Discount on Bonds Payable & & 2328.63 \\
\hline & Cash & & 15,000 \\
\hline \multirow{3}{*}{ 31-Dec-20 } & Interest Expense & $17,328.63$ & \\
\hline & Discount on Bonds Payable & & 2328.63 \\
\hline & Cash & & 15,000 \\
\hline \multirow{2}{*}{ 31-Dec-20 } & Bonds Payable & 300000 & \\
\hline & Cash & & 300000 \\
\hline
\end{tabular}




\section{JOURNAL ENTRIES FOR A BOND ISSUED AT A PREMIUM STRAIGHT LINE METHOD}

In this case, the amount of premium is evenly distributed among the eight semi-annual periods. The amount debited to Premium on Bonds Payable Account is equal to $2524.75(=20198 / 8)$. The interest expense would be equal to $\$ 12475.25$ (=15000 -2524.75). The corresponding journal entries are relatively simple as shown in Table 6 .

Table 6. Journal Entries for a Bond Sold at a Discount - Straight Line Method

\begin{tabular}{|c|c|c|c|}
\hline \multicolumn{4}{|c|}{ Journal Entries for a Bond Sold at Premium } \\
\hline Date & Account Name & Debit & Credit \\
\hline \multirow{3}{*}{ 1-Jan-17 } & Cash & 320,198 & \\
\hline & Premium on Bonds Payable & & 20198 \\
\hline & Bonds Payable & & 300,000 \\
\hline \multirow{3}{*}{ 30-Jun-17 } & Interest Expense & $12,475.25$ & \\
\hline & Premium on Bonds Payable & $2,524.75$ & \\
\hline & Cash & & 15,000 \\
\hline \multirow{3}{*}{ 31-Dec-17 } & Interest Expense & $12,475.25$ & \\
\hline & Premium on Bonds Payable & $2,524.75$ & \\
\hline & Cash & & 15,000 \\
\hline \multirow{3}{*}{ 30-Jun-18 } & Interest Expense & $12,475.25$ & \\
\hline & Premium on Bonds Payable & $2,524.75$ & \\
\hline & Cash & & 15,000 \\
\hline \multirow{3}{*}{ 31-Dec-18 } & Interest Expense & $12,475.25$ & \\
\hline & Premium on Bonds Payable & $2,524.75$ & \\
\hline & Cash & & 15,000 \\
\hline \multirow{3}{*}{ 30-Jun-19 } & Interest Expense & $12,475.25$ & \\
\hline & Premium on Bonds Payable & $2,524.75$ & \\
\hline & Cash & & 15,000 \\
\hline \multirow{3}{*}{ 31-Dec-19 } & Interest Expense & $12,475.25$ & \\
\hline & Premium on Bonds Payable & $2,524.75$ & \\
\hline & Cash & & 15,000 \\
\hline \multirow{3}{*}{ 30-Jun-20 } & Interest Expense & $12,475.25$ & \\
\hline & Premium on Bonds Payable & $2,524.75$ & \\
\hline & Cash & & 15,000 \\
\hline \multirow{3}{*}{ 31-Dec-20 } & Interest Expense & $12,475.25$ & \\
\hline & Premium on Bonds Payable & $2,524.75$ & \\
\hline & Cash & & 15,000 \\
\hline \multirow{2}{*}{ 31-Dec-20 } & Bonds Payable & 300000 & \\
\hline & Cash & & 300000 \\
\hline
\end{tabular}

\section{CONCLUSIONS}

In this paper, the complications that arise in posting journal entries for bonds issued at a discount or a premium are discussed. The calculations associated with the amortization of a bond discount or premium are described in detail in a simple manner so that even a freshman student can understand them easily. The effective interest rate method as recommend by GAAP is used in calculating the amounts of periodic interest payments, and also the amounts that can be debited to the annual interest expense account. Some hints and guidelines are also provided for recording the journal entries correctly for the bonds issued at a discount or a premium with focus on the important role of the actual amount of money received when a bond is sold. Students new to the accounting for bond issues may gain a better understanding of the requisite calculations and journal entries by following the steps outlined in this paper. 


\section{AUTHOR BIOGRAPHY}

Donald Joyner obtained his Ph. D. in Accounting from Virginia Commonwealth University, Richmond, VA in 2011. Currently, he is an assistant professor of Accounting in the Business, Leadership, and Management Department of the College of Arts and Sciences at Regent University, Virginia Beach, Virginia, USA. Prior to joining Regent, he worked as the CFO of a small credit union and was also elected treasurer of the City of Poquoson, Virginia.

\section{REFERENCES}

Averkamp, H. (2017). Bonds payable. Retrieved from https://www. Accountingcoach.com/bonds-payable/explanation/

Bragg, S. (2010). The amortization of premium on bonds payable. Retrieved from https://ww.accountingtools.com/articles/whatis-the-amortization-of premium-on-bonds-payable/

Bragg, S. (2014). Amortization of discount on bonds payable. Retrieved from https://ww.accountingtools.com/articles/what-isthe-amortization-of discount-on-bonds-payable/

Ehrhardt, M. C. \& Brigham, E. F. (2016). Corporate finance: A focused approach (6 ${ }^{\text {th }}$ ed.). Cengage Learning, Boston, MA.

Gordon, E. A., Raedy, J. S., \& Sannella, A. J. (2015). Intermediate accounting (1 $1^{\text {st }}$ ed.). Pearson Publishing, New York, NY.

Ingram, K. (2017). Adjusting journal entries - Accounting in focus. Ingram Digital Media, Inc. Retrieved from http://accountinginfocus.com/tag/adjusting-journal-entries/

Miller-Nobles, T. L., Mattison, B. L., \& Matsumura, E. M. (2015). Horngren's financial \& managerial accounting (5 $5^{\text {th }}$ ed.). Pearson Publishing, New York, NY. 


\section{APPENDIX}

Suppose that a bond is issued with a face value of $B$, maturity period of $m$ years, stated interest rate $i$, and with interest payable semi-annually. Then, the effective interest rate $r$ for the semi-annual period is equal to $i / 2$. Further, the number of interest payments, $n$ is equal to $2 * m$. The amount of interest payable for each semi-annual period is equal to $B r$. Further, suppose the prevailing market interest rate per annum is $y$. Then the effective market interest rate $\boldsymbol{x}$ for the semi-annual period is equal to $y / 2$. Of course, $x$ may be higher or lower or equal to the rate $r$. Let $M$ be the current market price of the Bond. Then the pertinent question is: How are the variables, $B, r, M, x$, and $n$ related to each other?

RESULT \#1: Intuitively, you can see that if the semi-annual interest rate $r$ on the bond is greater than the semi-annual market interest rate $x$ the market price of the bond $M$ will be greater than the face value of the bond $B$ and vice versa. This result is proved below. An assumption used in the proof is that the market interest remains the same for the life of the bond, which, often, is not the case. The algebra involves the use of discounted cash flows and present value concepts.

Market value of the bond $=$ present value of the $n$ interest payments + present value of the face value of the bond.

$$
\begin{aligned}
& M=\left[\frac{B r}{(1+x)}+\frac{B r}{(1+x)^{2}}+\frac{B r}{(1+x)^{3}}+\cdots+\frac{B r}{(1+x)^{n}}+\right] \frac{B}{(1+x)^{n}} \\
& =\frac{B r}{(1+x)^{n}}\left[(1+x)^{n-1}+(1+x)^{n-2}+\cdots+1\right]+\frac{B r}{(1+x)^{n}} \\
& =\frac{B r}{(1+x)^{n}}\left[\frac{(1+x)^{n-1}}{x}\right]+\frac{B r}{(1+x)^{n}} \\
& M-B=\frac{B r}{(1+x)^{n}}\left[\frac{(1+x)^{n}-1}{x}\right]+\frac{B}{(1+x)^{n}}-B \\
& =B r\left[\frac{(1+x)^{n}-1}{x(1+x)^{n}}\right]-B x\left[\frac{(1+x)^{n}-1}{x(1+x)^{n}}\right]=B(r-x)\left[\frac{(1+x)^{n}-1}{x(1+x)^{n}}\right]=P
\end{aligned}
$$

Also,

$$
B-M=B(x-r)\left[\frac{(1+x)^{n}-1}{x(1+x)^{n}}\right]=D
$$

If $x=r, M-B=0$, or $M=B$. Clearly, if the annual stated rate is equal to the annual market interest rate, the market price of the bond will be equal to the face value of the bond.

If $r>x>0$, then, $M-B>0$, or $M>B$. If the stated rate is higher than the market interest rate, the market price of the bond will be obviously higher than the face value of the bond. This implies that a buyer will be willing to pay the premium, $P=M-B$, to the seller of the bond. On the other hand, if $0<r<x$, then, $M-B<0$, or $B>M$. If the stated rate is less than the market interest rate, the market price of the bond will be obviously less than the face value of the bond. This implies that the seller has to be willing to sell the bond at a discount of $D=B-M$, to the buyer.

Example \#1: Let $B=300000, m=4, i=10 \%$. Interest is payable semi-annually.

Then, $n=2 * 4=8$, and $r=10 \% / 2=5 \%$. Further, let $y=12 \%$. Then, $x=12 \% / 2=6 \%$. 


$$
\begin{aligned}
& \text { Market Value, } M=\frac{B r}{(1+x)^{n}}\left[\frac{(1+x)^{n-1}}{x}\right]+\frac{B r}{(1+x)^{n}} \\
& =\frac{300000 * 05}{(1+0.06)^{8}}\left[\frac{(1+0.06)^{n}-1}{0.06}\right]+\frac{300000}{(1+0.06)^{8}}=93142+188229=2811371
\end{aligned}
$$

Then, discount, $D=300000-281371=18629$

Example \#2: Let $B=300000, m=4, I=10 \%$. Interest is payable semi-annually.

Then, $n=2 * 4=8$, and $r=10 \% / 2=5 \%$. Further, let $y=8 \%$. Then, $x=8 \% / 2=4 \%$.

$$
\begin{aligned}
& \text { Market Value, } M=\frac{B r}{(1+x)^{n}}\left[\frac{(1+x)^{n-1}}{x}\right]+\frac{B}{(1+x)^{n}} \\
& =\frac{300000 * .05}{(1+0.04)^{8}}\left[\frac{(1+0.04)^{n}-1}{0.04}\right]+\frac{300000}{(1+0.04)^{8}}=100996+219202=320198
\end{aligned}
$$

Then, Premium $P=320198-300000=20198$

RESULT \#2: Let $F$ denote the future value of a stream of cash flows at the market interest rate, and let $S=B r-M x$. Obviously, $S$ denotes the difference between the semi-annual interest paid on the bond and the amount of the semiannual interest payable at the market interest rate on the market price of the bond. Then, the future value of the stream of cash flows generated by $S$ is equal to the premium $P$, if $r>x$, and discount $D$, if $r<x$. To get the future value, the algebra involves the compounding of the cash flows to the time of maturity of the bond at the effective market interest rate.

From result \#1,

$$
\begin{aligned}
& B r-M x=B r-x\left[\frac{B r}{(1+x)^{n}}\left\{\frac{(1+x)^{n}-1}{x}\right\}\right]+\frac{B}{(1+x)^{n}} \\
& =B r-\frac{B r x}{(1+x)^{n}}\left\{\frac{(1+x)^{n}-1}{x}\right\}-\frac{B}{(1+x)^{n}} \\
& =B r-B r\left\{1-\frac{1}{(1+x)^{n}}\right\}-\frac{B x}{(1+x)^{n}}
\end{aligned}
$$

Or,

$$
B r-M x=S=\frac{B(r-x)}{(1+x)^{n}}
$$

If,

$$
\begin{aligned}
& r>x>0, \text { then, } B r-M x>0 . \\
& F(S)=(B r-M x)\left[1=(1+x)+(1+x)^{2}+\cdots+(1+x)^{n-1}\right] \\
& =(B r-M x)\left[\frac{(1+x)^{n}-1}{x}\right]=\frac{B(r-x)}{(1+x)^{n}}\left[\frac{(1+x)^{n}-1}{x}\right]=P
\end{aligned}
$$


If,

$$
\begin{aligned}
& 0<r<x \text {, then, } B r-M x<0 \text {, or } M x-B r>0 . \text { Then, } M x-B r=S=\frac{B(x-r)}{(1+x)^{n}} \\
& F(S)=(M x-B r)\left[1+(1+x)+(1+x)^{2}+\cdots+(1+x)^{n-1}\right] \\
& =(M x-B r)\left[\frac{(1+x)^{n}-1}{x}\right]=\frac{B(x-r)}{(1+x)^{n}}\left[\frac{(1+x)^{n}-1}{x}\right]=D
\end{aligned}
$$

Hence proof of result \#2. 


\section{NOTES}

